\title{
Peran pemerintah daerah dalam mendukung potensi indikiasi geografis produk pertanian
}

\section{Ranitya Ganindha ${ }^{1}$, Sukarmi ${ }^{2}$.}

${ }^{1}$ Ranitya Ganindha; Fakultas Hukum Universitas Brawijaya; Jl. MT. Haryono 169; Malang; 65145; Jawa Timur; Indonesia.

${ }^{2}$ Sukarmi; Fakultas Hukum Universitas Brawijaya; Jl. MT. Haryono 169; Malang; 65145; Jawa Timur; Indonesia.

\section{ART I C LEINFO}

Article history:

Received 2020-05-04

Received in revised form

2020-05-11

Accepted 2020-05-18

Kata kunci:

Indikasi Geografis; Kabupaten

Malang; Pemerintah Daerah;

Produk Pertanian.

\section{Keywords:}

Geographical Indications; Malang

Regency; Local Government;

Agricultural Products.

DOI: https://doi.org/10.26905/

idjch.v11i2.3970.

How to cite item:

Ganindha, R., E Sukarmi, S.

(2020). Peran pemerintah daerah dalam mendukung potensi indikiasi geografis produk pertanian. Jurnal Cakrawala Hukum, 11(2). doi:10.26905/ idjch.v11i2.3970.

Corresponding Author:

* Ranitya Ganindha.

E-mail address: ranityag88@gmail.com

\section{Abstrak}

Pencatatan Indikasi Geografis sendiri memiliki manfaat yang dapat meningkatkan keuntungan secara ekonomis terhadap produk. Pendaftaran Sertifikasi Indikasi Geografis dapat meningkatkan potensi atas suatu produk hasil kekayaan hayati. Keuntungan yang didapatkan apabila suatu produk terlindungi oleh Indikasi Geografis adalah produk tersebut akan lebih unggul dan berdaya saing lebih tinggi dibanding dengan produk sejenis. Pemerintah daerah Kabupaten Malang serta komunitas lokal petani di Kabupaten Malang memiliki kesadaran terkait perlindungan Indikasi geografis. Salah satu program yang dicanangkan pemerintah melalui Kementerian Hukum dan HAM adalah Peningkatan Jumlah Indikasi Geografis. Pendaftaran Indikasi Geografis tidak saja memberi Peningkatan secara ekonomis, namun juga memiliki dampak panjang terhadap kemajuan sektor pariwisata sebgaai salah satu program unggulan yang ingin dicapai Pemerintah Kabupaten Malang. Penelitian ini adalah penelitian Yuridis Empiris dengan penafsiran kualitatif. Penelitian dengan metode empiris memiliki arti penelitian tersebut dilakukan secara langsung di lapangan untuk melakukan identifikasi masalah dan mencari solusi atas permasalahan yang terjadi. Luaran yang dihasilkan melalui penelitian ini adalah kajian, Rancangan Peraturan Daerah, serta jurnal yang dapat menjadi bahan rujukan bagi Pemerintah Kabupaten Malang.

\begin{abstract}
The recording of Geographical Indications itself has benefits that can increase the economic benefits of the product. Registration of Geographical Indication Certification can increase the potential of a product of biological wealth. The advantage that is obtained if a product is protected by Geographical Indications is that the product will be superior and have higher competitiveness compared to similar products. The
\end{abstract}




\section{Jurnal Cakrawala Hukum, Volume 11 No. 2 Agustus 2020 \\ ISSN PRINT 2356-4962 ISSN ONLINE 2598-6538}

local government of Malang Regency and local farming communities in Malang Regency have awareness regarding the protection of Geographical Indications. One of the programs launched by the government through the Ministry of Law and Human Rights is the Increase in the Number of Geographical Indications. Registration of Geographical Indications not only gives an economic increase, but also has a long impact on the progress of the tourism sector as one of the superior programs that the Malang Regency Government wants to achieve. This research is a juridical empirical research with a qualitative interpretation. Research using the empirical method means that the research is carried out directly in the field to identify problems and find solutions to problems that occur. The outputs produced through this research are studies, draft regional regulations, and journals that can be used as reference material for the Malang Regency Government.

\section{Pendahuluan}

Salah satu program yang unggulan Kekayaan Intelektual yang diusung Pemerintah adalah Indikasi Geografis (untuk selanjutnya disebut IG). Perlindungan Hukum IG menjadi hal penting untuk diperhatikan oleh Pemerintah daerah karena perolehan sertifikasi IG atas suatu produk berpotensi meningkatkan nilai ekonomis atas suatu komoditas dan menjadikan daerah memiliki hak eksklusif atas penggunaan komoditas tersebut (Lindsey, 2006). Hak atas IG telah tercantum pada ketentuan pasal (1) angka 7 dalam Undang-Undang Merek dan IG yang menyatakan bahwa Hak atas Indikasi Geografis merupakan suatu hak ekslusif yang diberikan negara kepada pemegang Indikasi Geografis yang telah terdaftar sepanjang produk yang telah didatarkan tersebut memiliki reputasi, kualitas dan ciri khas yang menjadikan dasar atau petunjuk diberikannya perlindungan atas Indikasi Geografis yang telah ada (Pasal 1 Angka 7 Undang-Undang Nomor 20 Tahun 2016 tentang Merek dan Pendaftaran Indikasi Geografis).

Berdasarkan data Direktorat Jenderal Kekayaan Intelektual (DJKI) hingga pertengahan 2018 terdapat 59 produk asal Indonesia yang telah tercatat dalam sertifikasi Indikasi Geografis. Beberapa komoditas yang telah mendapatkan tersebut di antaranya adalah Kopi Toraja, Kopi Gayo, Salak Pondoh, Ubi Cilembu, Mete kubu Bali dan lain sebagainya. Manfaat yang didapatkan melalui pendaftaran Indikasi Geografis tersebut adalah posisi nilai tawar yang lebih tinggi dibanding barang sejenis yang mengakibatkan peningkatan nilai jual komoditas, perlindungan hukum, serta peningkatan potensi agrowisata.

Hingga saat ini tercatat untuk Provinsi Jawa Timur, baru dua komoditas produk yang telah terdaftar Indikasi Geografis yaitu Kopi Raung dan Bandeng asap Sidoarjo. Padahal Jawa Timur memiliki banyak sekali produk unggulan yang sudah memiliki nama di pasar nasional maupun internasional seperti misalnya Durian Merah Banyuwangi, Mangga Harum Manis Probolinggo, Apel Batu, Apel Malang, Kopi Dampit, Ubi Ungu Gunung Kawi, Pisang Mas Kirana, dan lain-lain.

Riset yang dilakukan di Kabupaten Malang menunjukkan bahwa hingga saat ini belum ada satupun produk pertanian di Kota Malang yang telah tersertifikasi dalam Indikasi Geografis. Padahal, fakta empiris di lapangan menunjukkan terdapat beberapa produk yang memiliki potensi untuk didaftarkan Indikasi Geografis. Produk tersebut di antaranya adalah: Kopi Dampit, Kecamatan Dampit memiliki ratusan hektar perkebunan Kopi, Kualitas Kopi Dampit sendiri telah mendapatkan nama tersendiri bagi penikmat Kopi, Kontur Geografis Kabupaten Malang menjadikan Kopi Dampit memiliki jejak rasa vanilla. Ubi Ungu di 


\section{Peran pemerintah daerah dalam mendukung potensi indikiasi geografis produk pertanian}

Ranitya Ganindha, Sukarmi

Kabupaten Wonosari memiliki keunikan khas, serta Apel Poncokusumo.

Perlindungan Indikasi Geografis telah diatur dalam Perjanjian (TRIPs) atau Trade of Related Aspects of Intellectual Property Rights. tersebut membawa implikasi yang mengharuskan semua negara anggota untuk menyusun peraturan terkait Indikasi Geografis dengan tujuan memberikan perlindungan hukum. Perlindungan hukum terhadap hak IG merupakan salah satu kekhususan yang termasuk bagian dari tanggung jawab daerah yang otonom. Oleh karena itu, Pemda perlu menentukan kebijakan dalam rangka memberikan jaminan perlindungan akan hak IG yang ada di daerahnya, sebagai bentuk kepedulian terhadap kekayaan daerah tersebut (Lukito, 2018). Indonesia adalah negara anggota World Trade Organization (WTO) sehingga implikasinya adalah Indonesia wajib untuk menerima segala perjanjian yang dibuat oleh WTO termasuk di dalamnya adalah TRIPs.

Indikasi Geografis adalah salah satu tanda yang dapat menunjukkan asal barang suatu daerah dengan faktor lingkungan geografis seperti faktor alam, manusia dan atau kombinasi dari keduanya (Nugroho, 2020). Sertifikasi IG memiliki tujuan agar dapat meningkatkan daya saing suatu produk pertanian. Melalui keunikan yang dimiliki citra rasa dari produk pertanian dari hasil produksi suatu daerah yang daerah lain tidak memiliki.

Produk yang potensial dan dapat masuk dalam perlindungan Indikasi geografis salah staunya dapat berupa produk pertanian dan pangan dengan syarat produk-produk terseut mengusung nama tempat asal dan memiliki kualitas yang memang langsung dipengaruhi dari ciri khas asal tempat. Melalui sertifikasi Indikasi geografis suatu produk pertanian dapat memiliki daya saing yang jauh lebih tinggi dibandingkan produk setipe. Kelebihan tersebut didapatkan melalui karakteristik unik dari citra suatu produk pertanian yang berasal dari suatu wilayah.

Salah satu persyaratan untuk mendapatkan indikasi geografis bagi produk pertanian adalah keunikan rasa yang berbeda dibandingkan produk lainnya. Setiap daerah terdapat ciri keunikan serta ciri khas yang tidak dapat digantikan atau ditukar. IG akan menuntut adanya penjelasan terkait daerah penghasil dari keterangan asal barang tersebut, yang menjadikan kopi ini tidak bisa digantikan dengan daerah penghasil lainnya (Connor, 2005).

Hak kekayaan intelektual adalah salah satu sumber daya yang memiliki nilai ekonomi bagi pemilik haknya apabila didaftarkan dan digunakan secara profesional. Perlindungan dalam Hak Kekayaan Intelektual melingkupi Hak Kebendaan yang berasal dari kinerja otak seseorang (Mulyono, 2019). Dalam peraturan perundang-undangan di Indonesia, cakupan perlindungan Hak Kekayaan Intelektual meliputi Hak Cipta, Desain Industri Merek, Paten, Rahasia Dagang, Tata Letak Sirkuit Terpadu, dan perlindungan varietas tanaman. Secara kategoris hasil kreasi intelektual pada rezim HKI biasanya di bedakan ke dalam "Hak Cipta" dan "Hak Milik Industri" (Djaja, 2016). Tidak semua cakupan HKI diatur dalam Undang-Undang tersendiri, seperti misalnya ketentuan Indikasi geografis yang diatur dalam Undang-Undang Merek. Konsep Pemerintahan saat ini adalah berdasar sistem Desentralisasi. Daerah memiliki otonomi sendiri untuk melakukan pengurusan terhadap pemerintahannya sebagai perwujudan asas otonomi daerah dengan memperhatikan prinisp demokrasi, pemerataan, keadilan yang bertujuan untuk meningkatkan kesejahteraan masyarakat. salah satu wujud kepedulian Pemerintah daerah tersebut diwujudkan melalui penentuan kebijakan dalam rangka memberikan jaminan dan perlindungan terhadap kekayaan daerah.

Potensi daerah salah satunya dapat dikembangkan untuk melahirkan ciri dari daerah tersebut adalah potensi yang berkaitan dengan produk asli daerah, seperti produk-produk unggulan yang merupakan produk-produk yang melekat pada pengetahuan tradisional dan kearifan lokal. Produk-produk tersebut dapat berupa bidang pertanian, perikanan, dimana produk-produk nya 


\section{Jurnal Cakrawala Hukum, Volume 11 No. 2 Agustus 2020}

ISSN PRINT 2356-4962 ISSN ONLINE 2598-6538

memerlukan adanya perlindungan dari hukum dan menjadi sarana untuk promosi dalam pemasarannya (Nugroho, 2020).

Setiap orang dapat melakukan kreasi dan memberikan karya dari hasil pikirannya, energi dan dana yang memiliki manfaat untuk kehidupan manusia melahirkan salah satu kompensasi yang terkait hak yang boleh dikomersialkan oleh sang pemilik dari kekayaan intelektual tersebut dan hal itu juga dapat memberikan suatu keuntungan finansial (Kartadjoemana, 1997). Penguatan ekonomi tidak lepas dari pengelolaan potensi dan pemanfaatan yang ada guna mencapai kesejahteraan masyarakat (Nugroho, 2013).

Hak kekayaan intelektual adalah salah satu sumber daya yang memiliki nilai ekonomi bagi pemilik haknya apabila didaftarkan dan digunakan secara profesional. Perlindungan dalam Hak Kekayaan Intelektual melingkupi Hak Kebendaan yang berasal dari kinerja otak seseorang. Dalam peraturan perundang-undangan di Indonesia, cakupan perlindungan Hak Kekayaan Intelektual meliputi Rahasia Dagang, Hak Cipta, Desain Industri, Merek, Paten, Tata Letak Sirkuit Terpadu, dan perlindungan varietas tanaman. Tidak semua cakupan HKI diatur dalam Undang-Undang tersendiri, seperti misalnya ketentuan Indikasi geografis yang diatur dalam Undang-Undang Merek.

Keunggulan Negara Indonesia adalah kekayaan sumber daya alam yang sangat bervariasi dan melimpah sehingga perlindungan melalui instrumen hak kekayaan intelektual berupa produk indikasi geografis perlu diperhatikan. Terkait produk kopi, Indonesia memiliki lebih dari 300 varian jenis kopi baik jenis robusta, kopi arabika dan bahkan kopi liberika. Akan tetapi, hanya tiga belas jenis kopi yang telah tecatat sebagai indikasi geografis.

\section{Metode}

Jenis penelitian ini adalah penelitian yuridis empiris, yakni yang mencakup penelitian terhadap identifikasi hukum dalam hal ini tindakan yang dilakukan langsung terjun ke lapangan agar dapat mencari fakta yang terjadi serta yang mencakup penelitian terhadap efektivitas hukum (Fajar, 2009). Penelitian ini menganalisa data yang diperoleh langsung dari responden, yaitu dari pihak pemerintah daerah Kabupaten Malang terkait peran yang telah dilakukan untuk mendukung Indikasi Geografis dan Hambatan serta Upaya yang telah dilakukan untuk menanggulanginya.

Metode pendekatan yuridis sosiologis, adalah metode yang dijadikan pada penelitian ini adalah yaitu sebuah penelitian yang mengutamakan pembahasan yuridis artinya berpedoman pada aturan yang dapat dijadikan dasar untuk menganalisa gejala-gejala hukum yang timbul (Sedarmayanti \& Hidayat, 2002). Pendekatan yuridis sosiologis membantu penelitian untuk mengetahui bagaimana aturan terkait Indikasi Geografis dalam Hukum Hak Kekayaan Intelektual dikaitkan dengan potensi komoditas produk Kabupaten Malang dalam mendapatkan sertifikasi.

\section{Pembahasan}

Eksistensi Hukum Atas Kekayaan Intelektual (HAKI) telah melahirkan kekuatan ekonomi di berbagai negara maju, seperti Amerika Serikat, dan Jepang. Salah satu elemen HAKI yang menjadi banyak perhatian negara termasuk Indonesia adalah Indikasi Gografis (IG). Hal ini sudah dimulai sejak era tahun delapan puluhan, HAKI semakin berkembang baik di bidang ekonomi, ataupun industri serta perdagangan level internasional, HAKI bernilai penting. Ketentuan ini ditandai oleh adanya suatu peningkatan pendaftaran IG di Direktorat Jenderal HKI. Data Ditjen HKI dari tahun 2008-2016 tercatat sebanyak 46 (empat puluh enam) IG yang telah didatftarkan (Margono, 2002).

Potensi daerah salah satunya dapat dikembangkan untuk melahirkan ciri dari daerah tersebut adalah potensi yang berkaitan dengan produk asli daerah, seperti produk-produk unggulan 


\section{Peran pemerintah daerah dalam mendukung potensi indikiasi geografis produk pertanian}

Ranitya Ganindha, Sukarmi

yang merupakan produk-produk yang melekat pada pengetahuan tradisional dan kearifan lokal. Produk-produk tersebut dapat berupa bidang pertanian, perikanan, dimana semua produk membutuhkan adanya perlindungan secara hukum dan menjadi sarana untuk promosi dalam pemasarannya (Agus, 2005).

Setiap orang dapat melakukan kreasi juga menciptakan hasil karya yang berasal dari pikirannya, energi dan dana yang memiliki manfaat untuk kehidupan manusia melahirkan kompensasi dalam hal suatu hak yang boleh dikomersialkan bagi pemilik kekayaan intelektual nya dan hal itu juga dapat memberikan suatu keuntungan finansial (Kartadjoemana, H.S, 1997). Penguatan ekonomi tidak lepas dari pengelolaan potensi dan pemanfaatan yang ada guna mencapai kesejahteraan masyarakat (Nugroho, 2013).

Indikasi Geografis adalah sebuah nama dagang yang dapat dikaitkan, dipakai atau dilekatkan pada suatu kemasan dalam produk dan berfungsi dalam menunjukkan asal tempat produk dibuat. Tempat asal memberikna karakteristik atau ciri khusus yang kualitas produk tersebut amat dipengaruhi oleh tempat asalnya, sehingga produk ini bernilai tertentu di mata konsumen, dimana hal ini menjadikan bahwa tempat asli memiliki kelebihan khusus dalam menghasilkan suatu produk (Ayu, 2006). Sehingga perlindungan hukum dan pengembangan HAKI diperlukan khususnya potensi IG di Indonesia perlu mendapat perhatian yang tinggi terutama oleh berbagai pihak agar potensi ini tidak habis terekploitasi oleh pihak asing yang tidak bertanggung jawab. Salah satu aspek hak khusus pada HKI adalah hak ekonomi (economic rights), yakni hak untuk memperoleh keuntungan ekonomi atas kekayaan intelektual (Sarmilah, 2015).

Perlindungan rezim Indikasi Geografis sangat penting untuk dikembangkan di negaranegara Asia terutama Indonesia (Usman, 2003). Tidak hanya menjadi Hak Kekayan Intelektual dimana perlindungan hukum cukup terbuka atas pengaruh keragaman budaya negara di dunia, Indikasi Geografis selain itu juga menghargai nilai historis diantara asal tempat suatu produk. Karakter yang menujukkan unsur kepemilikannya bernilai kolektif atau komunal. Indikasi Geografis sangat berpotensial juga dalam menjamin supaya keuntungan ekonomis dapat dirasakan dari suatu produk oleh produsen dari berbagai daerah asal produk. Contohnya, Indikasi Geografis di beberapa negara maju mampu menaikkan standar kehidupan masyarakat nya secara signifikan.

Perkembangan perdagangan dunia yang dipelopori oleh kemajuan teknologi telah menyumbang berbagai perubahan dunia yang cukup besar. Kemajuan teknologi didukung oleh semakin meleknya masyarakat untuk memberikan perlindungan terhadap HAKI. Kedua, IG merupakan konsep HAKI yang bersifat kolektif sehingga perlindungan hukum dan pengembangannya menuntut kerjasama semua elemen, baik pemerintah daerah, pengusaha, akademisi, maupun kelompok masyarakat. Ketiga, pentingnya perlindungan IG agar tidak ada lagi kasus pelanggaran IG yang dilakukan oleh praktik bisnis curang yang tentunya dapat merugikan Indonesia.

Perlindungan atas suatu kekayaan intelektual untuk terhadap potensi IG adalah hal mutlak, dikarenakan IG adalah jenis HAKI yang berbasis pada potensi sumber daya alam yang ruang lingkupnya sangat luas seperti pertaian, perkebunan, ataupun kerajian tangan tertentu yang berbahan baku dari alam yang memiliki ciri khas tertentu, dan memiliki reputasi (Saidin, 2004.) yang dapat dilindungi dengan IG, dengan perlindungan hukum diharapkan dapat menambah nilai pemasukan bagi masyarakat. Selain produk yang harus melalui proses produksi ada juga beberapa produk yang merupakan produk dan hasil alam yang memiliki ciri khas tertentu dan berbeda antar daerah dengan yang lainnya dalam hal cita rasa, hal ini disebabkan oleh faktor natural alam sera geografis, 
contoh: kopi toraja, jeruk Pontianak, apel malang, kopi gayo.

Petani adalah pihak yang lebih lemah dalam kegiatan bisnis. Petani dianggap tidak memiliki kemampuan dan rasa mandiri sejak awal. Rendahnya pemahaman akan kegiatan bisnis itu sendiri menjadikan Petani rentan menjadi objek kesewenangan tengkulak, rentenir, spekulan dan bahkan kebijakan pemerintah itu sendiri. Petani tidak dapat menentukan harga prosuknya sendiri. Petani hanya menjadi alat atau buruh dalam kegiatan pertanian itu sendiri (Margono, Suyud, 2010).

Keuntungan dalam perlindungan IG, pertama, dalam hal penggunaan secara komersial melalui kekayaan intelektual bisa dinikmati oleh pemilik kekayaan nya. sehingga pemilik berhak secara langsung memperoleh kompensasi finansial yang terjadi melalui proses transaksi yang berkaitan dengan kekayaan intelektual yang digunakan. Kedua, pemilik dapat pula memperoleh kompensasi finansial atau menjual dengan memperbolehkan penggunaan hak atas kekayaan intelektual melalui persetujuan dengan pihak lain. Ketiga, pemilik juga dapat dapat membatasi atau mencegah pihak lain dalam memperoleh dan mempergunakannya (Margono, 2010).

Produk-produk potensial tersebut dikenal dalam kekhasannya dan timbul akibat adanya interaksi antar komoditas dengan lingkungan, sosial budaya, dan teknologi setempat. Kekhasan tersebut tidak dapat ditemukan di lokasi lain, pun jika komoditas atau bahan bakunya berdasarkan bahan baku yang sama. Kekhasan yang dimiliki oleh produk-produk yang ada menjadi nilai keunggulan produk dan wilayah tersebut dari produk yang sama berasal dari wilayah lain (Hadi, 1979).

Indonesia memiliki berbagai produk hail cerminal dari indikasi geografis, yang memerlukan aturan yang tegas dan perlindungan supaya kekayaan dan produk-produk lokal mendapatkan kepastian hukum. Upaya perlindungan hukum terhadap IG secara normatif diatur dalam UU Nomor
15 tahun 2001 tentang Merek yang diganti sekarang menjadi Undang-Undang Nomor 20 Tahun 2016 Tentang Merek dan Indikasi Geografis. Mechanisme pendafatarannya lalu diatur dalam Peraturan Pemerintah No 51 tahun 2007 tentang IG. Karena luasnya ruang lingkup IG UU Nomor 41 Tahun 2009 tentang perkebunan Juncto PP Nomor 31 tahun 2009 terkait Perlindungan Wilayah Geografis juga ikut mengatur ketentuan IG.

Akibat hukum adanya pendaftaran IG, tentunya menghalangi eksportir komiditi dari Negara lain untuk memasukkan produk pertanian seperti kopi, apel ataupun ubi yang menggunakan tanda dengan nama yang sudah terdaftar (Sumiyati, Ramli, \& Iskandar, 2008). Perlindungan hukum HKI bersifat teritorial. Secara logis, masyarakat memiliki unsur kepemilikan terhadap produk ber IG karena mempunyai kepentingan secaa langsung dengan IG tersebut. Tetapi pada struktur perlindungan hukum, perlindungan IG membutuhkan usaha proaktif oleh pihak yang mempunyai kepentingan atau dalam hal ini (komunitas pemilik) mulai dari pendaftaran atas kepemilikannya. Hal penting lain dari Indikasi Geografis merupakan konsistensi pada suatu produk dengan mengusung nama suatu wilayah.

Tujuan perlindungan Indikasi Geografis untuk melindungi nilai tambah, mutu dari produk, serta menjadi pengembangan pedesaan. Indikasi Geografis (IG) adalah suatu komponen Hak Kekayaan Intelektual (HKI) yang bernilai penting pada sektor perdagangan, terutama dalam memberikan perlindungan untuk komoditas perdagangan berkait pada tempat produl asal barang atau nama daerah. Sehingga dapat dihitung besar nilai dari ekonomi kekayaan Indikasi Geografis, contohnya Kopi Arabika Kintamani, yang mempunyai potensi ekonominya yang besar untuk komunitas masyarakat Kintamani di Bali. Secara tidak langsung, Indikasi Geografis yang didaftarakan dapat memacu pedesaan dalam pertumbuhan ekonomi (Mawardi, 2009) reputasi produk suatu wilayah akan meningkat dengan indikasi geografis. 


\section{Peran pemerintah daerah dalam mendukung potensi indikiasi geografis produk pertanian}

Ranitya Ganindha, Sukarmi

Pendaftaran indikasi geografis akan meningkatkan nilai dan reputasi suatu produk yang jika dikembangnkan dalam jangka lebih lebar, maka dapat dimanfaatkan oleh penduduk sekitar dan pemerintah daerah dengan pengembangan agrowisata, serta pengolahan produk yang memiliki nilai jual lebih tinggi (Surip, 2009). Kondisi tersebut akan menumbuhkan peningkatan perekonomian dari sketor pertanian. Dari 60 produk pertanian yang terdaftar dalam Indikasi Geografis di Indonesia, 22 adalah produk Kopi. Indikasi geografis memang ditujukan untuk melindungi produk secara hukum, namun, secara ekonomis Petani dapat merasakan peningkatan harga jual kopi.

\section{Peran pemerintah daerah dalam pendaftaran indikasi geografis}

Perlindungan indikasi geografis memberikan keuntungan terhadap nilai produk hingga bernilai semakin tinggi, maka indikasi geografis mampu mengembangkan dan menggerakkan perekonomian dari daerah asal produk dari indikasi geografis. Hal tersebut tercermin pada saat ini banyak produk-produk yang berbasis pengetahuan tradisional dari negara-negara maju telah berhasil memberikan manfaat finansial bagi masyarakatnya (Sudarmanto, 2005). Konsep dari indikasi geografis merupakan perlindungan komunal, maka dalam tahap perlindungan indikasi geografis pelaksanaannya dapat dilakukan secara bersamasama melalui pemberdayaan oleh kalangan LSM, dapat juga dengan kerjasama di dinas-dinas pemerintah, warga sekitar dengan menulis uraian dari produknya yang akan didaftarkan menjadi indikasi geografis. Jumlah dari indikasi geografis terdaftar di Indonesia relative banyak, namun tidak ada monitoring (Aulia, 2005). Indikasi geografis akan dilindungi dan mendapat perhatian setelah didaftarkan, dimana sistem HAKI indonesia menganut prinsip first to file, yang datang dan mendaftar pertama akan dilayani.

Perlindungan hukum serta pengembangan potensi produk IG menjadi salah satu sarana untuk pemerintah daerah dan beberapa pemangku kepentingan untuk menciptakan kekuatan ekonomi lokal. Melalui perlindungan optimal IG tidak saja menguntungkan kelestarian lingkungan yang dapat terjaga, namun juga pengembangan sumber daya alam dan manusia di daerah dapat dimaksimalkan. Di samping itu, dengan terciptanya peluang potensi tersebut, akan memiliki nilai ekonomi yang tidak kecil di daerah tersebut.

Di beberapa negara di Asia juga telah terdapat pendaftaran indikasi geografis contoh di India dan Thailand yang sejak lama sudah ada, sayangnya Indonesia baru memulai menjalankan aturan IG setelah adanya aturan UU No 20 Tahun 2016. Sebelumnya tim ahli pada bidang indikasi geografis serta aspek biaya terkait mendapat revisi yang diatur pada PP No. 51 tahun 2007 tentang pemeriksaan secra substantif indikasi geografis yang belum ada.

Permasalahan terkait hak kekayaan intelektual akan bersentuhan dengan berbagai aspek seperti aspek teknologi, industri, budaya, sosial, serta aspek lainnya. Aspek dalam hal teknologi salah satu yang merupakan factor dominan dalam perlindungan dan perkembangan hak kekayaan intelektual. Dalam perkembangan teknologi secara informasi cukup relative cepat saat membentuk dunia terasa semakin sempit, informasi dengan mudah dapat tersebar ke berbagai belahan dunia. Pada keadaan inilah hak kekayaan intelektual menjadi semakin penting, sebab hak kekayaan intelektual menjadi hak secara monopoli yang boleh digunakan agar melindungi investasi serta boleh dialihkan haknya. Namun yang menjadi aspek terpenting apabila dihubungkan pada upaya perlindungan atas hak intelektual ialah aspek hukum. Dimana aspek Hukum ditujukan untuk dapat mengatasi berbagai permasalahan yang timbul pada hak kekayaan intelektual. Hukum harus mampu melindungi hasil intelektual, agar dapat mengembangkan nilai daya kreasi setiap orang. 


\section{Jurnal Cakrawala Hukum, Volume 11 No. 2 Agustus 2020}

ISSN PRINT 2356-4962 ISSN ONLINE 2598-6538

Beberapa wujud perlindungan terhadap indikasi geografis adalah sanksi bagi pelaku tindak pidana yang melanggar ketentuan dari indikasi geografis serta indikasi-asal disebut dalam Undang Undang Merek pada pasal 92. Dalam Indikasi geografis penekanan nya tidak serta merta pada merek saja, namun juga pada asal produk itu berasal, hal ini juga karena merek kepemilikannya secara individu tetapi indikasi geografis kepemilikannya adalah kolektif.

Indikasi geografis tentunya tidak sama dengan aspek HAKI, contoh merek, desain industry, paten, dan hak cipta sebab indikasi geografis yang menjadi pemohon ialah lembaga-lembaga dari perwakilan masyarakat asli asal daerah dimana barang diproduksi, lembaga pemerintah daerah diberikan wewenang baik tingkat provinsi maupun kabupaten.

UU Nomor 23 tahun 2014 mengatur tentang Pemerintah Daerah dihimbau agar dapat mempercepat perwujudan kesejahteraan masyarakat dengan pemberdayaan, peningkatan pelayanan, peningkatan daya saing daerah, serta peran serta masyarakat,. Lebih lanjut dalam peraturan menteri dalam negeri nomor 9 tahun 2014 mengatur hal pedoman pengembangan produk daerah unggulan juga mengamanatkan bahwa potensi ekonomi daerah perlu dikembangkan secara optimal menjadi produk unggulan daerah yang berdaya saing dan dapat meningkatkan kesejahteraan masyarakat sesuai dengan kondisi dan kekhasan daerah, yang didukung dengan peningkatan kapasitas kelembagaan daerah yang mandiri dan tangguh serta menuangkan pengembangan untuk produk daerah unggulan pada dokumen terkait perencanaan daerah.

Permohonan Indikasi Geografis dapat diajukan oleh Lembaga yang mewakili untuk produk yang berupa sumber daya alam, kerajinan tangan dan hasil industri serta dapat diajukan oleh Pemerintah Daerah Kota/Kabupaten. Ketentuan tersebut diatur dalam UU Merek dan Indikasi Geografis.
Pemerintah daerah memiliki peranan penting dalam proses pendaftaran Indikasi geografis. Kurangnya jumlah produk yang tidak terindikasi geografis, salah satunya disebabkan karena kurangnya peranan dari Pemerintah Daerah (Suhartono, 2018). Petani Lokal atau masyarakat kurang menyadari bahwa indikasi geografis memiliki potensi keuntungan. Pemerintah Daerah harusnya berperan untuk meningkatkan kesadaran serta berinisiatif untuk melakukan pengembangan potensi indikasi geografis.

Perlindungan Hukum yang dilakukan oleh Pemerintah Daerah dapat dilakukan melalui pendekatan karakter komulatif dan kolektif agar lebih sejalan dengan konsep kepemilikan Indonesia yang bersifat komunal (Anggraeni, Nita, 2013). Kepemilikan Indikasi Geografis sendiri tidak hanya dimiliki oleh satu orang melainkan satu wilayah.

Undang-Undang Merek dan Indikasi Geografis melalui pasal 70 dan 71 telah memberikan kewenangan kepada Pemerintah daerah dalam urusan melakukan pengawasan dan membina Indikasi Geografis. Kewenangan yang dimiliki tersebut harusnya lebih dioptimalkan oleh Pemerintah Daerah. Pemerintah Daerah membantu dari proses pendaftaran hingga penata kelolaannya sesuai dengan azas pemerintahan yang baik.

\section{Kendala dan hambatan dalam pendaftaran indikasi geografis produk pertanian kabupaten Malang}

Letak Geografis Kabupaten Malang yang dikelilingi oleh pegunungan menjadikan Kabupaten Malang memiliki karakteristik produk pertanian

Berdasarkan hasil pengamatan lapang dan wawancara yang dilakukan dengan dinas terkait (Dini, 2019) penulis mengambil kesimpulan bahwa kendala timbul karena sebagian besar petani belum memiliki kesadaran akan pentingnya Indikasi Geografis serta belum memiliki kesadaran hukum tentang perlunya perlindungan potensi IG didaerahnya sedangkan dari sisi pemerintah daerahkendala 


\section{Peran pemerintah daerah dalam mendukung potensi indikiasi geografis produk pertanian}

Ranitya Ganindha, Sukarmi

tersebut muncul dari kendala teknis berupa pendanaan. Adapun berdasar hasil wawancara, kendala tersebut adalah: Pemerintah Daerah Kota Malang belum Memiliki Peraturan daerah khusus terkait Indikasi Geografis. Tidak semua bidang aturan membutuhkan peraturan khusus di tingkat daerah. Namun, keberadaan peraturan daerah tersebut dapat menjadi landasan dalam kegiatan pembinaan dan pengawasan.

Alokasi anggaran dana dari pemerintah daerah tidak hanya untuk pendaftaran indikasi geografis suatu prosuk saja, namun dari APBD yang ada harus dibagi untuk komoditas lain dan alokasi lainnya, seperti halnya yang diinginkan oleh Presiden Jokowi yakni memajukan memajukan pangan, seperti : padi, jagung, gandum, tebu, dll, sehingga harus dikesampingkan untuk mencapai sertifikasi indikasi geografis. Akan tetapi, pihak pemda sudah melakukan banyak hal seperti halnya membangun ekowisata (wisata edukasi) kopi di dampit, karena dengan hal ini akan membantu untuk mempersiapkan kopi dampit mendapatkan sertifikasi indikasi geografis, rehab bibit, bantuan pupuk, ada integrasi kopi dan ternak. Sosialiasi ke kelompok tani, agar mampu menguasai dari hulu ke hilir, sehingga dapat memproduksi dan menjual produk kopi, serta bantuan untuk gagal panen. Bantuan intensifikasi untuk pupuk. Serta menyediakan sekolah lapang pengendalian hama terpadu untuk tanaman kopi untuk menstimulan produk kopi yang berkualitas, ini merupakan salah satu reward kepada petani kopi, Prosedur pendaftaran yang rumit, membutuhkan satu tahun anggaran, untuk waktu 3 triwulan. Membutuhkan persiapan yang matang agar pengambilan sampling kopi memiliki kualitas yang baik.

Tingkat Pemahaman Dinas Terkait mengenai indikasi geografis masih belum memadai. Dinas Pertanian memaknai bahwa dengan melakukan pendampingan terhadap petani berarti telah membantu proses Indikasi Geografis tersebut. Pemerintah Daerah harusnya lebih mendorong Petani untuk meningkatkan pehamaman terkait pentingnya indikasi geografis. Kelompok Petani yang kurang mendukung: seperti misalnya pada komoditas kopi Dampit, Kelompok petani kopi dampit terdapat kurang lebih 445 kelompok petani kopi, satu kelompok tani terdiri dari 20-25 orang anggota dari semua anggota petani kopi, tidak semuanya setuju dan paham untuk mendapatkan sertifikasi IG, banyak petani yang hanya memikirkan uang, sehingga langsung dijual ke tengkulak, bukan untuk jangka panjang. Bahkan kopi yang belum matang berwarna merah sudah dipetik untuk dijual agar mendapatkan uang.

Petani yang masih konservatif, banyak petani yang tidak peduli, dan tidak mau untuk maju, sehingga dibutuhkan kerja ekstra untuk membuat petani mau untuk melakukan sertifikasi IG. Sulit untuk meyakinkan petani, ada ketakutan sendiri terhadap petugas dinas, seperti apa keuntungan untuk para petani nantinya. Sehingga dibutuhkan kerjasama yang saling bersinergi antara pemda dan juga petani kopi. Oleh karena itu agar potensipotensi IG yang ada di daerah ini bisa berkembang dengan baik dan mendapatkan perlindungan hukum, maka pemberdayaan SDM dan pengembangan kelembagaan perlu ditingkatkan sebagai salah satu upaya perlindungan terhadap keaslian dan kekhasan produk di Kabupaten Malang.

\section{Kesimpulan}

Pencatatan Indikasi Geografis sendiri memiliki manfaat yang dapat meningkatkan keuntungan secara ekonomis terhadap produk. Indikasi Geografis adalah suatu tanda untuk menunjukkan asal daerah dari suatu barang berdasarkan faktor lingkungan geografis contohnya faktor alam, atau factor manusia dapat juga kombinasi kedua dari faktor tersebut, sehingga produk dengan Indikasi Geografis memiliki karakteristik citarasa yang unik. Pendaftaran Sertifikasi Indikasi Geografis dapat meningkatkan potensi atas suatu produk 


\section{Jurnal Cakrawala Hukum, Volume 11 No. 2 Agustus 2020}

ISSN PRINT 2356-4962 ISSN ONLINE 2598-6538

hasil kekayaan hayati. Sertifikasi Indikasi Geografis dapat berguna agar meningkatkan nilai saing dari produk pertanian. Perlindungan indikasi geografis memberikan nilai ekonomis bagi suatu daerah, karena akan meningkatkan nilai jual suatu produk dengan mengusung kekhasan daerah tertentu.

Produk pertanian merupakan salah satu produk yang memiliki potensi untuk dapat dilindungi dengan Indikasi Geografis. Sesuai dengan amanat Undang-Undnag, Pemerintah Daerah memiliki kewenangan untuk melakukan pendaftaran Indikasi Geografis atas Produk daerahnya. Minimnya pendafataran Indikasi Geografis salah satunya disebabkan oleh kurangnya peran Pemerintah daerah dalam proses pembinaan. Terdapat beberapa hambatan yang dialami oleh Pemerintah Daerah Kabupaten Malang dalam menjalankan perannya dalam pendaftaran Indikasi Geografis. Hambatan tersebut diantaranya adalah kesadaran Petani yang masih rendah dan hanya berorientasi pada keuntungan sesaat, Pemahaman Dinas terkait terhadap Indikasi Geografis yang masih kurang memadai, Alokasi anggaran yang kurang mencukupi, serta prosedur pendaftaran Indikasi Geografis yang dianggap rumit. Peranan Pemerintah daerah sangat diperlukan dalam pendaftaran sertifikat indikasi geografis baik melalui sosialisasi, penguatan lembaga, maupun penyususnan.

\section{Daftar pustaka}

Connor, J. M., 2005. Proc Fixing Overchanges : Legal and Economic Evidence. Purdue University.

Direktorat Jenderal Hak Kekayaan Intelektual. 201. Prosedur Pendaftaran Indikasi Geografis. (online) Diunduh(http://www.dgip.go.id/ebscript/ publicportal.cgi?.ucid=376\&ctid=25\&id=1783\&type=0). (1 Juni 2017).

Djaja, H. (2016). Perlindungan hukum terhadap ekspresi budaya tradisional dalam perspektif undang undang hak cipta. Jurnal Cakrawala Hukum, 7(1), 18-29. doi:10.26905/idjch.v7i1.1790.
Mulyono, G. (2019). Perlindungan Hukum Terhadap Tata Penglolaan Air di Indonesia. Jurnal Cakrawala Hukum, 10(1), 18-29. doi:10.26905/idjch.v10i1.3292.

Lukito, I. (2018). Peran Pemerintah Daerah dalam Mendorong Potensi Indikasi Geografis (Studi pada Provinsi Kepulauan Riau). Jurnal Ilmiah Kebijakan Hukum, 12(3), 313-330. doi:http:// dx.doi.org/10.30641/kebijakan.2018.V12.313330 .

Nugroho, H. (2020). Perlindungan Hukum bagi Para Pihak dalam Transaksi Pinjaman Online. Jurnal Hukum Positum, 5(1), 32-41. https://doi.org/ 10.35706/positum.v5i1.3482.

Peraturan Pemerintah Republik Indonesia Nomor 50 Tahun 2007 tentang Pendaftaran Indikasi Geografis.

Usman, Rachmadi. 2003. Hukum Hak Atas Kekayaan Intelektual : Perlindungan dan Dimensi Hukumnya di Indonesia. Bandung. Alumni.

Saidin. 2004. Aspek Hukum Hak Kekayaan Intelektual. Intellectual Property Rights. Jakarta. Raja Grafindo.

Sarmilah, M. (2015). Legal Protection Against Geographical Indications of Registered Brands by Others Who Have No Rights. Unnes Law Journal, 4(2). https://doi.org/10.15294/ulj.v4i2.38783.

Sedarmayanti \& Syarifudin Hidayat. 2002. Metode Penelitian. Bandung. Mandar Maju.

Suhartono, S. (2018). Eksistensi Fatwa Majelis Ulama Indonesia dalam Perspektif Negara Hukum Pancasila. Al-Ihkam: Jurnal Hukum Dan Pranata Sosial, 12(2), 448-465. doi:http://dx.doi.org/ 10.19105/al-ihkam.v12i2.1255.

Sumiyati, Y., Ramli, T., \& Iskandar, R. (2008). Kajian Yuridis Sosiologis mengenai Indikasi Geografis sebagai Sumber Pendapatan Asli Daerah (PAD). MIMBAR : Jurnal Sosial dan Pembangunan, 24(1), 79-88. doi:https://doi.org/10.29313/mimbar. v24i1.256.

Surip, Mawardi. 2009. Establishment of Geographical Indication Protection System in Indonesia, Case in Coffee, Worlwide Symposium on Geographical Indications jointly orginized by the World Intellectual Property Organization (WIPO) and the Patent Office of the Republic of Bulagaria, Sofia, June 1 - 12, 2009, hlm. 11. 


\section{Peran pemerintah daerah dalam mendukung potensi indikiasi geografis produk pertanian}

Ranitya Ganindha, Sukarmi

Hadi, Sutrisno. 1979. Metodelogi Riset. Yogyakarta. UGM Press.

Lindsey. 2006. Hak Kekayaan Intelektual: Suatu Pengantar. Bandung. Alumni.
Undang-Undang Dasar Negara Republik Indonesia Tahun 1945.

Undang-Undang Republik Indonesia Nomor 20 Tahun 2016 tentang Merek dan Indikasi Geografis. 